\title{
In situ degradability of elephant grass ensiled with increasing levels of pineapple agro-industrial byproduct
}

\author{
Degradabilidade in situ do capim elefante ensilado com níveis \\ crescentes de subproduto da agroindústria do abacaxi
}

\author{
Ana Cristina Holanda Ferreira ${ }^{1}$; Norberto Mario Rodriguez ${ }^{2}$; \\ José Neuman Miranda Neiva ${ }^{1}$; Patrícia Guimarães Pimentel ${ }^{3 *}$; Silas Primola Gomes ${ }^{4}$; \\ Warley Efrem Campos ${ }^{5}$; Fernando César Ferraz Lopes ${ }^{6}$; Ivone Yurika Mizubuti ${ }^{7}$; \\ Guilherme Rocha Moreira ${ }^{8}$
}

\begin{abstract}
The objective of this study was to evaluate the in situ degradability of dry matter (DM), crude protein (CP), neutral detergent fiber (NDF), acid detergent fiber (ADF) and hemicellulose of elephant grass (Pennisetum purpureum, Schum.) with increasing levels $\left(0 ; 35.0 ; 70.0,105.0\right.$, and $140.0 \mathrm{~g} \mathrm{~kg}^{-1}$ ) of dried pineapple (Ananas comosus, L.) byproduct (DPBP). The experimental silos consisted of plastic drums with $210 \mathrm{~L}$ capacity. After weighing and homogenizing the elephant grass with the DPBP, the material was inserted in the silos (126 kg silage, at a density of $\left.600 \mathrm{~kg} \mathrm{~m}^{-3}\right)$ and compressed. After 45 days of ensilage, silos were opened and samples of the silages were collected for the trial. The study of degradability in situ was conducted using a rumen-fistulated steer. The animal was fed with corn silage supplemented with $1 \mathrm{~kg}$ concentrate daily. Five levels of addition of the byproduct were tested, with three replicates and five times of incubation with an animal. The experimental design was completely randomized with split plots, in which the proportions of DPBP were the treatments (plots), the different silos were the replicates, and the incubation times were the subplots. The levels of inclusion of DPBP provided an increase $(\mathrm{P}<0.05)$ in disappearance of $\mathrm{DM}$ and $\mathrm{CP}$ and in the effective degradability of $\mathrm{DM}, \mathrm{NDF}, \mathrm{ADF}$ and hemicellulose. The dried pineapple byproduct is a potential alternative to be used as additive in the ensilage of elephant grass, as it provides an increase in the rumen degradability parameters.
\end{abstract}

Key words: Agroindustrial waste. Digestibility. In situ degradation. Intake. Rumen.

\footnotetext{
${ }^{1}$ Profs. Drs, Universidade Federal do Tocantins, UFT, Escola de Medicina Veterinária e Zootecnia, Araguaína, TO, Brasil. E-mail: anacristinahf@hotmail.com; araguaia2007@gmail.com

2 Prof. Dr., Departamento de Zootecnia, Universidade Federal de Minas Gerais, UFMG, Escola de Veterinária, Belo Horizonte, MG, Brasil. E-mail: norberto.bhe@terra.com.br

${ }^{3}$ Prof $^{\mathrm{a}}$ Dra $^{\mathrm{a}}$, Departamento de Zootecnia, Universidade Federal do Ceará, UFC, Fortaleza, CE, Brasil. E-mail: pgpimentel@ hotmail.com

${ }^{4}$ Prof. Dr., Universidade da Integração Internacional da Lusofonia Afro-Brasileira, UNILAB, Instituto de Desenvolvimento Rural, Redenção, CE, Brasil. E-mail: silas.primola@unilab.edu.br

${ }^{5}$ Fiscal Federal Agropecuário, Ministério da Agricultura, Pecuária e Abastecimento, MAPA, Departamento de Fiscalização de Insumos Pecuários, Brasília, DF, Brasil. E-mail: warley.campos@agricultura.gov.br

${ }^{6}$ Pesquisador Dr., Empresa Brasileira de Pesquisa Agropecuária, EMBRAPA, Centro Nacional de Pesquisa de Gado de Leite, Juiz de Fora, MG, Brasil. E-mail: fernando.lopes@embrapa.br

${ }^{7}$ Prof $^{a}$ Dr $^{\mathrm{a}}$, Departamento de Zootecnia, Universidade Estadual de Londrina, UEL, Londrina, PR, Brasil. E-mail: mizubuti@uel.br

${ }^{8}$ Prof. Dr., Departamento de Estatística e Informática, Universidade Federal Rural de Pernambuco, UFRPE, Recife, PE, Brasil. E-mail: guirocham@gmail.com

* Author for correspondence
} 


\section{Resumo}

Avaliaram-se a degradabilidadein situ da matéria seca (MS), proteína bruta (PB), fibra em detergente neutro (FDN), fibra em detergente ácido (FDA) e hemicelulose das silagens de capim elefante (Pennisetum purpureum, Schum.) com níveis crescentes (0;35,0;70,0;105,0 e 140,0 $\mathrm{g} \mathrm{kg}^{-1}$ ) do subproduto do abacaxi (Ananas comosus, L.) desidratado (SABD). Como silos experimentais, foram utilizados tambores plásticos de $210 \mathrm{~L}$ de capacidade. Em cada silo foram colocados $126 \mathrm{~kg}$ de forragem, de forma que atingisse uma densidade de $600 \mathrm{~kg} \mathrm{~m}^{-3}$. Após a pesagem e homogeneização do capim elefante com o SABD, o material foi compactado no interior do silo, durante o carregamento. Após 45 dias de ensilagem, os silos foram abertos, e coletadas amostras das silagens para realização do ensaio de degradabilidade. O estudo de degradabilidade in situ foi conduzido utilizando um bovino adulto macho, fistulado no rúmen, alimentado com silagem de milho suplementada com concentrado $1 \mathrm{~kg} \mathrm{dia}^{-1}$. Os cinco níveis de adição do subproduto foram testados com três repetições e cinco tempos de incubação, em delineamento inteiramente casualizado com parcelas subdivididas, sendo as proporções de SABD, os tratamentos (parcelas); os diferentes silos eram as repetições e os tempos de incubação eram as subparcelas. Os níveis de inclusão do SABD proporcionaram aumento $(\mathrm{P}<0,05)$ no desaparecimento da MS, PB e nas degradabilidades efetivas da MS, FDN, FDA e hemicelulose. O subproduto do abacaxi desidratado constitui alternativa potencial para ser utilizado como aditivo na ensilagem do capim elefante, pois promove incremento nos parâmetros de degradabilidade ruminal.

Palavras-chave: Consumo. Degradação in situ. Digestibilidade. Resíduo agroindustrial. Rúmen.

\section{Introduction}

Theuse of elephant grass(Pennisetumpurpureum, Schum) for silage making is strategic because of the seasonal production of forage in tropical regions. However, in the ideal developmental stage for ensilage, three factors limit the production of goodquality silage: the low soluble-carbohydrate content, the high buffer capacity, and the high moisture content (FERRARI JÚNIOR; LAVEZZO, 2001). Corsi et al. (2001) suggested that in order to obtain grass silage of satisfactory quality and reduced losses, these restrictions should be corrected by the addition of sugars and an increase in dry matter contents.

Inclusion of additives, with absorbent properties, increases the dry matter content, ensuring better conditions for desirable fermentations (EVANGELISTA et al., 2000). Besides, the inclusion of soluble-carbohydrate sources improves the fermentation process, making the silage of tropical grasses a feed of adequate nutritional value (FERRARI JÚNIOR; LAVEZZO, 2001). Ferreira et al. (2007) found that including dried pineapple byproduct improved the fermentation process and the nutritional characteristics of elephant grass silage, highlighting its potential as an additive.

The industrialization of fruits for juice or pulp production generates byproducts with a high potential to be used in ruminant feeding. The use of agroindustrial waste has become an attractive alternative for animal nutrition in fruit-growing regions, given the quality of ingredients and their low cost. The waste obtained from the industrial processing or the discarded fruits are not used much in animal feeding, and studies on their nutritional values and modes of use are very rare. One of the ways to preserve this waste from tropical fruits is ensilage (LLANO et al., 2008; HERRERA et al. 2009).

The processing of pineapple (Ananas comosus L.) in the industries generates waste like skin, crown, shoots, ground fruit parts, and pulp. The composition may change according to the quality and variety of the fruit. The good nutritive value of pineapple waste is because of its organic matter constitution, consisting mostly of fibrous and soluble carbohydrates, despite the low crude protein content (UPADHYAY et al., 2010). 
In this scenario, the objective of this study was to evaluate the in situ degradability of elephant grass silage with increasing levels of dried pineapple byproduct.

\section{Material and Methods}

Five levels of inclusion of dried pineapple byproduct (DPBP) were used in the ensilage of the elephant grass $(0 ; 35.0 ; 70.0 ; 105.0$ and 140.0 $\mathrm{g} \mathrm{kg}^{-1}$, as fed), which was harvested manually at approximately 70 days of growth and processed through a conventional forage shredder machine to a particle size of 1 to $2 \mathrm{~cm}$ (Tables 1 and 2). Later, the chopped grass was mixed with the DPBP, which was acquired from the processing of the fruit for the extraction of juice and pulp at the company MAISA, located in Mossoro-RN, Brazil.

Table 1. Chemical composition of the feedstuffs.

\begin{tabular}{lcc}
\hline Item & $\mathrm{EG}^{1}$ & $\mathrm{DPBP}^{2}$ \\
\hline $\mathrm{DM}^{3}$ & 206.0 & 874.0 \\
$\mathrm{CP}^{4}\left(\mathrm{~g} \mathrm{~kg}^{-1} \mathrm{DM}\right)$ & 33.6 & 92.8 \\
$\mathrm{NDF}^{5}\left(\mathrm{~g} \mathrm{~kg}^{-1} \mathrm{DM}\right)$ & 736.9 & 607.4 \\
$\mathrm{ADF}^{6}\left(\mathrm{~g} \mathrm{~kg}^{-1} \mathrm{DM}\right)$ & 488.5 & 241.2 \\
$\mathrm{Hemicellulose}\left(\mathrm{g} \mathrm{kg}^{-1} \mathrm{DM}\right)$ & 248.5 & 366.2 \\
Cellulose $\left(\mathrm{g} \mathrm{kg}^{-1} \mathrm{DM}\right)$ & 344.8 & 113.0 \\
Lignin $\left(\mathrm{g} \mathrm{kg}^{-1} \mathrm{DM}\right)$ & 143.7 & 105.1 \\
$\mathrm{NIDN}^{7}$ & 236.4 & 188.8 \\
$\mathrm{ADIN}^{8}$ & 139.1 & 41.4 \\
\hline
\end{tabular}

${ }^{1} \mathrm{EG}$ - elephant grass; ${ }^{2} \mathrm{DPBP}$ - byproduct from dried pineapple; ${ }^{3} \mathrm{DM}$ - dry matter; ${ }^{4} \mathrm{CP}$ - crude protein; ${ }^{5} \mathrm{NDF}$ - neutral detergent fiber; ${ }^{6} \mathrm{ADF}$-Acid detergent fiber; ${ }^{7} \mathrm{NDIN}$ - neutral detergent insoluble nitrogen $\left(\mathrm{g} \mathrm{kg}^{-1}\right.$ of total nitrogen); ${ }^{8} \mathrm{ADIN}$ - acid detergent insoluble nitrogen ( $\mathrm{g} \mathrm{kg}^{-1}$ of total nitrogen).

Table 2. Chemical composition of the silages.

\begin{tabular}{lccccc}
\hline \multirow{2}{*}{ Item } & \multicolumn{5}{c}{$\mathrm{DPBP}^{1}$} \\
\cline { 2 - 5 } & 0.0 & 35.0 & 70.0 & 105.0 & 140.0 \\
\hline $\mathrm{DM}^{2}$ & 193.8 & 204.0 & 232.0 & 247.7 & 275.4 \\
$\mathrm{CP}^{3}\left(\mathrm{~g} \mathrm{~kg}^{-1} \mathrm{DM}\right)$ & 47.7 & 53.4 & 55.5 & 59.2 & 59.7 \\
$\mathrm{NDF}^{4}\left(\mathrm{~g} \mathrm{~kg}^{-1} \mathrm{DM}\right)$ & 765.5 & 734.4 & 709.9 & 689.9 & 664.1 \\
$\mathrm{ADF}^{5}\left(\mathrm{~g} \mathrm{~kg}^{-1} \mathrm{DM}\right)$ & 488.0 & 457.3 & 427.7 & 426.2 & 396.7 \\
Hemicellulose $\left(\mathrm{g} \mathrm{kg}{ }^{-1} \mathrm{DM}\right)$ & 277.4 & 277.1 & 282.2 & 263.7 & 267.5 \\
Cellulose $\left(\mathrm{g} \mathrm{kg}^{-1} \mathrm{DM}\right)$ & 344.7 & 322.2 & 307.1 & 305.5 & 282.1 \\
Lignin $\left(\mathrm{g} \mathrm{kg}^{-1} \mathrm{DM}\right)$ & 143.3 & 135.1 & 120.7 & 120.6 & 114.6 \\
$\mathrm{NDIN}$ & 216.4 & 213.5 & 234.1 & 211.1 & 199.4 \\
$\mathrm{ADIN}$ & & 87.6 & 91.3 & 92.1 & 74.8 \\
\hline
\end{tabular}

${ }^{1} \mathrm{DPBP}$ - byproduct from dried pineapple; ${ }^{2} \mathrm{DM}$ - dry matter; ${ }^{3} \mathrm{CP}$ - crude protein; ${ }^{4} \mathrm{NDF}$ - neutral detergent fiber; ${ }^{5} \mathrm{ADF}$-Acid detergent fiber; ${ }^{\mathrm{N} D I N}$ - neutral detergent insoluble nitrogen ( $\mathrm{g} \mathrm{kg}^{-1}$ of total nitrogen); ${ }^{7} \mathrm{ADIN}$ - acid detergent insoluble nitrogen ( $\mathrm{g} \mathrm{kg}^{-1}$ of total nitrogen). 
The byproduct was composed basically of the pineapple skin and pulp resulting from the processing. The material was dried in the sun on a cemented floor for $48 \mathrm{~h}$, scattered in layers of approximately $7 \mathrm{~cm}$ in thickness, and turned over at least three times daily until it reached 130.0 to 160.0 $\mathrm{g} \mathrm{kg}^{-1}$ moisture. At night, the material was piled and covered with canvass to avoid accumulation of moisture.

The experimental silos were made of plastic drums with $210 \mathrm{~L}$ capacity in four replicates. The material was manually mixed to homogeneity. After weighing and homogenizing the elephant grass with the DPBP, the material was inserted in the silos (126 kg silage, at a density of $600 \mathrm{~kg}$ $\mathrm{m}^{-3}$ ) and compressed. After the silos were filled up, they were closed with plastic canvas secured with rubber bands.

After 45 days of ensilage, silos were opened and samples of the silages were collected for the trial. Samples were pre-dried in a forcedventilation oven at $60^{\circ} \mathrm{C}$ for $72 \mathrm{~h}$, processed in a knife mill with $5 \mathrm{~mm}$ sieve, and homogenized for later incubation. The in situ degradability study was conducted using a rumen-fistulated steer (TOMICH; SAMPAIO, 2004). The animal was fed corn silage supplemented with $1 \mathrm{~kg}$ concentrate daily, at $07 \mathrm{~h} 00$ and $16 \mathrm{~h} 00$.

Five levels of addition of the byproduct were tested, with three replicates and five times of incubation. The experimental design was completely randomized, with split-plots, in which the proportions of DPBP were the treatments (plots), the different silos were the replicates, and the incubation times were the sub-plots.

The feeds were incubated in $9 \times 20 \mathrm{~cm}$ nylon bags with $50-\mu \mathrm{m}$ porosity containing $10 \mathrm{~g}$ of the pre-dried material. Bags were introduced in the rumen at $08 \mathrm{~h} 00$ and removed in sequential order at 6; 24; 48 and $96 \mathrm{~h}$, and then washed manually in running water. To determine zero time $(t=0)$, three nylon bags were used per treatment with the same amount of sample utilized for the other incubation times; these were sealed and washed manually in the same manner as the other times.

Afterwards, they were dried in a forced-air oven at $60^{\circ} \mathrm{C}$ and weighed, and samples were analyzed to determine dry matter (DM) (AOAC, 1990) and crude protein (CP) (AOAC, 1990). The levels of neutral detergent fiber (NDF), acid detergent fiber (ADF), hemicellulose, cellulose and lignin were determined in accordance with the Van Soest et al. (1991). Concentrations of NDF were analyzed using $1 \mathrm{~g}$ of sample treated with heat-stable alphaamylase and solubilized with $100 \mathrm{~mL}$ of neutral detergent solution and expressed without correction for residual nitrogen and ash. The levels of ADF were determined through sequential method and expressed without correction for residual nitrogen and ash. The levels of lignin were determined using solubilization of cellulose with sulfuric acid ( $72 \% \mathrm{H}_{2} \mathrm{SO}_{4}$ ) according to Van Soest et al. (1991). The neutral (NDIN) and acid (ADIN) detergent insoluble nitrogen contents were determined according to methodologies described by Licitra et al. (1996).

The model was evaluated by Akaike's information criterion (AIC), as follows:AIC $=-2 \ln L$ $+2(p+1)$,in which, $\mathrm{L}$ is the likelihood function; $\mathrm{n}$ is the sample size; and $\mathrm{p}$ is the number of free parameters of the model. Means were compared and coefficients of the model proposed by Ørskov and McDonald (1979) were determined on SAS software (Statistical Analysis System, version 9.2). After determining the model parameters, the effective degradability (ED) was estimated by adopting the rumen passage rates of $0.02 ; 0.05$ and $0.08 \mathrm{~h}^{-1}$ (McDONALD, 1981).

\section{Results and Discussion}

The disappearance of DM and CP of treatments increased linearly with the duration of ruminal incubation (Table 3). An effect $(\mathrm{P}<0.05)$ of incubation time and addition of DPBP was observed 
on the disappearance of DM from the silages (Table 3). The soluble fractions ranged from 194.3 to 240.1 $\mathrm{g} \mathrm{kg}^{-1}$ among the evaluated treatments.

Regarding the effect of incubation period, all silages displayed increasing values $(\mathrm{P}<0.05)$ for DM disappearance until $96 \mathrm{~h}$. At all studied times, the silages with $140.0 \mathrm{~g} \mathrm{~kg}^{-1} \mathrm{DPBP}$ as fed showed higher $(\mathrm{P}<0.05)$ DM disappearance values than those observed in the silage made exclusively with elephant grass and with addition of 35.0 and $70.0 \mathrm{~g}$ $\mathrm{kg}^{-1} \mathrm{DPBP}$ as fed.

During the time interval of 6 to $48 \mathrm{~h}$ of incubation, the DM disappearance values were higher in the silages with $140.0 \mathrm{~g} \mathrm{~kg}^{-1} \mathrm{DPBP}$ as fed as compared with the exclusive elephant grass silages. Silage values leveled off at $96 \mathrm{~h}$.

Table 3. Average disappearance $\left(\mathrm{g} \mathrm{kg}^{-1}\right)$ of the nutrients from silages at time zero and at different rumen incubation times.

\begin{tabular}{cccccc}
\hline \multirow{2}{*}{ Tempo (h) } & \multicolumn{5}{c}{ DPBD $^{1}$} \\
\cline { 2 - 6 } & 0.0 & 35.0 & 70.0 & 105.0 & 140.0 \\
\hline 0 & $194.3 \mathrm{cE}$ & $196.5 \mathrm{cE}$ & $215.9 \mathrm{Be}$ & $240.1 \mathrm{aE}$ & $230.5 \mathrm{aE}$ \\
6 & $225.9 \mathrm{dD}$ & $246.9 \mathrm{cD}$ & $283.1 \mathrm{bD}$ & $304.1 \mathrm{aD}$ & $307.0 \mathrm{aD}$ \\
24 & $341.8 \mathrm{dC}$ & $376.0 \mathrm{cC}$ & $429.3 \mathrm{bC}$ & $420.4 \mathrm{bC}$ & $449.4 \mathrm{aC}$ \\
48 & $454.5 \mathrm{cB}$ & $457.3 \mathrm{cB}$ & $496.9 \mathrm{bB}$ & $503.9 \mathrm{bB}$ & $541.1 \mathrm{aB}$ \\
96 & $610.4 \mathrm{bcA}$ & $597.8 \mathrm{cA}$ & $626.2 \mathrm{bA}$ & $645.6 \mathrm{aA}$ & $646.5 \mathrm{aA}$ \\
Equations* & $\mathrm{Y}=214.2+4.3 \mathrm{x}$ & $\mathrm{Y}=234.0+4.1 \mathrm{x}$ & $\mathrm{Y}=269.5+4.0 \mathrm{x}$ & $\mathrm{Y}=282.5+4.0 \mathrm{x}$ & $\mathrm{Y}=291.2+4.1 \mathrm{x}$ \\
$\mathrm{R}^{2}$ & 0.98 & 0.95 & 0.92 & 0.95 & 0,90 \\
\hline \multicolumn{5}{c}{$\mathrm{Crude}$ protein } \\
\hline 0 & $161.0 \mathrm{cE}$ & $181.0 \mathrm{bcE}$ & $205.6 \mathrm{abE}$ & $220.0 \mathrm{aE}$ & $211.6 \mathrm{aE}$ \\
6 & $244.4 \mathrm{cD}$ & $272.5 \mathrm{bD}$ & $286.8 \mathrm{bD}$ & $291.7 \mathrm{bD}$ & $320.0 \mathrm{aD}$ \\
24 & $389.8 \mathrm{dC}$ & $402.3 \mathrm{cdC}$ & $427.6 \mathrm{bcC}$ & $450.5 \mathrm{abC}$ & $469.0 \mathrm{aC}$ \\
48 & $444.5 \mathrm{~dB}$ & $523.8 \mathrm{cB}$ & $533.1 \mathrm{bcB}$ & $554.5 \mathrm{abB}$ & $571.9 \mathrm{aB}$ \\
96 & $687.6 \mathrm{cA}$ & $651.6 \mathrm{dA}$ & $715.8 \mathrm{bA}$ & $718.0 \mathrm{bA}$ & $759.1 \mathrm{aA}$ \\
Equations* & $\mathrm{Y}=207.4+5.1 \mathrm{x}$ & $\mathrm{Y}=244.2+4.7 \mathrm{x}$ & $\mathrm{Y}=257.3+5.1 \mathrm{x}$ & $\mathrm{Y}=273.2+5.0 \mathrm{x}$ & $\mathrm{Y}=281.0+5.3 \mathrm{x}$ \\
$\mathrm{R}^{2}$ & 0.96 & 0.92 & 0.96 & 0.94 & 0,94 \\
\hline
\end{tabular}

${ }^{\mathrm{a}, \mathrm{b}}$ Means followed by different letters in the row are different by $\mathrm{t}$ test $(\mathrm{P}<0.05) .{ }^{\mathrm{A}, \mathrm{B}}$ Means followed by different letters in the column are different by $t$ test $(\mathrm{P}<0.05)$. ${ }^{1} \mathrm{DPBP}$ - byproduct from dried pineapple. ${ }^{*}$ - significant at $1 \%$ probability level by $\mathrm{t}$ test. ns - not significant at $5 \%$ probability level by $t$ test. $\mathrm{R}^{2}$ - coefficient of determination. Coefficient of experimental variation $(\mathrm{CV})$ of dry matter $=1.59 \%$ and of crude protein $=6.1 \%$.

The observed DM disappearance values (Table 3) are rather high for fibrous feeds with a low level of soluble carbohydrate, especially because a good part of these compounds is consumed during the ensilage process. Therefore, these values seem to result from the loss of particles from the pores of the nylon bags in the moment of washing. Working with the addition of byproduct from the annatto industry, Rêgo et al. (2010) observed an increase in
DM disappearance up to the level of $133.7 \mathrm{~g} \mathrm{~kg}^{-1}$ DM of addition of the byproduct to the ensilage of elephant grass for $48 \mathrm{~h}$ of incubation, which is close to that observed in the present study.

As regards the incubation period, it is believed that at $96 \mathrm{~h}$, the silages had already reached maximum DM disappearance. Sampaio (1994) recommended the incubation time of $96 \mathrm{~h}$ for in situ 
rumen evaluation studies of roughages, considering that up to this time, changes can be detected in the degradability of the material. The higher DM disappearance values $(\mathrm{P}<0.05)$ observed at 6 and $48 \mathrm{~h}$ in the silages with addition of $140.0 \mathrm{~g} \mathrm{~kg}^{-1}$ DPBP must be related to the increased amount of soluble material in the silages, since reductions were detected in the NDF, ADF, cellulose and lignin contents with addition of DPBP (Table 2). This difference in the fibrous fractions may influence DM intake, because the rumen fill is a limiting factor to feed intake, and it is negatively correlated with NDF (VAN SOEST, 1994).

Unlike the results recorded in the present study, in which greater DM disappearance values were found in the silages with increase in the levels of addition of DPBP, Rogério (2005) observed that only at the incubation time of $6 \mathrm{~h}$ did the pineapple byproduct show higher DM disappearance values (346.4 $\left.\mathrm{g} \mathrm{kg}^{-1} \mathrm{DM}\right)$ than elephant grass $\left(302.7 \mathrm{~g} \mathrm{~kg}^{-1}\right.$ DM), stabilizing at $12 \mathrm{~h}$ and $24 \mathrm{~h}$ of incubation, while the elephant grass displayed increasing values until 96 h. However, at 96 h, both feeds showed the highest DM disappearance rate (592.8 and $687.9 \mathrm{~g}$ $\mathrm{kg}^{-1} \mathrm{DM}$, respectively). According to the author, this response is related to the nutritional characteristics of the evaluated elephant grass compared with the pineapple byproduct. Nevertheless, in the present study, the DPBP showed a better nutritional value, with a lower fraction of cell wall components than the elephant grass (Tables 1 and 2).

In determining the disappearance of $\mathrm{CP}$, it was found that both the incubation time and the levels of addition of DPBP to the ensilage of elephant grass interfered $(\mathrm{P}<0.05)$ with the disappearance of $\mathrm{CP}$, with increasing values for all levels of addition of the byproduct (Table 3).

Concerning the influence of the level of inclusion of the byproduct in the disappearance of $\mathrm{CP}$, at zero time (0), the silages containing 70.0; 105.0 and $140.0 \mathrm{~g} \mathrm{~kg}^{-1} \mathrm{DPBP}$ as fed showed a higher $(\mathrm{P}<0.05)$ disappearance value than the silage made with elephant grass only. At $96 \mathrm{~h}$, the exclusive elephant grass silage showed a similar $(\mathrm{P}>0.05) \mathrm{CP}$ disappearance value to that observed in the silage with $35 \mathrm{~g} \mathrm{~kg}^{-1}$ DPBP as fed, but lower $(\mathrm{P}>0.05)$ than that obtained in the silages containing $70.0 ; 105.0$ and $140.0 \mathrm{~g} \mathrm{~kg}^{-1} \mathrm{DPBP}$ as fed.

The higher $(\mathrm{P}<0.05) \mathrm{CP}$ disappearance values (Table 3) in the silages containing 70.0; 105.0 and $140.0 \mathrm{~g} \mathrm{~kg}^{-1}$ DPBP as fed as compared with the exclusive elephant grass silage may be related to the increase in the CP contents of the silages in which the byproduct was included (Table 2). Habib et al. (2013) stated that many studies have shown that the rumen CP degradation kinetics of highprotein byproducts are strongly affected by intrinsic variation in feedstuffs, e.g., plant cultivars, growing conditions, and processing methods, and extrinsic factors, such as bag pore size and substrate particle size.

Evaluating the pineapple byproduct, Rogério (2005) cited that the disappearance of CP from the byproduct increased to $135.8 \mathrm{~g} \mathrm{~kg}^{-1}$ from 6 to $12 \mathrm{~h}$ of incubation, showing lowest degradation at $24 \mathrm{~h}$, and then increased again to $148.2 \mathrm{~g} \mathrm{~kg}^{-1}$ at $48 \mathrm{~h}$, with the greatest disappearance observed at $96 \mathrm{~h}(731.1$ $\left.\mathrm{g} \mathrm{kg}^{-1}\right)$. In a comparison with elephant grass, the author noted that the CP disappearance values were always increasing, and higher than the pineapple byproduct. These results differ from the response observed in the current study, in which higher CP disappearance rates were founds in the silage with substitution of the elephant grass for DPBP. This response can be attributed to the higher $\mathrm{CP}$ content and lower concentration of ADIN in DPBP as compared with elephant grass. However, Rogério (2005), as previously mentioned, utilized elephant grass of lower nutritional value, which explains the higher disappearance rates of this grass in relation to the pineapple byproduct.

Pereira et al. (2009) evaluated cashew, pineapple and acerola (Malpighia emarginata) wastes and concluded that these wastes are 
characterized as good sources of NDIN, which would provide a greater flow of amino acids into the intestine, since this fraction is slowly degraded in the rumen and thus has a high escape rate. However, this was not observed in the present study. Habib et al. (2013) stated that many studies have shown that the rumen $\mathrm{CP}$ degradation kinetics of high-protein byproducts are strongly affected by intrinsic variation in feedstuffs, e.g., plant cultivars, growing conditions, and processing methods, and extrinsic factors, such as bag pore size and substrate particle size.
The disappearance of NDF, ADF and hemicellulose of treatments increased linearly with the duration of ruminal incubation (Table 3), with the exception for hemicellulose with $105.0 \mathrm{~g} \mathrm{~kg}^{-}$ ${ }^{1} \mathrm{DPBP}$ as fed $(\mathrm{P}>0.05)$. With regard to the effect of the addition of DPBP on the disappearance of NDF at each incubation time, it was observed that the silages with $140.0 \mathrm{~g} \mathrm{~kg}^{-1} \mathrm{DPBP}$ as fed showed higher $(\mathrm{P}<0.05) \mathrm{NDF}$ disappearance values than the silages containing elephant grass alone, except for the incubation time of $96 \mathrm{~h}$, at which the exclusive elephant grass silages had higher $(\mathrm{P}<0.05)$ values than the others (Table 4).

Table 4. Average disappearance $\left(\mathrm{g} \mathrm{kg}^{-1}\right)$ of the nutrients from silages at time zero and at different rumen incubation times.

\begin{tabular}{|c|c|c|c|c|c|}
\hline \multirow{2}{*}{ Tempo (h) } & \multicolumn{5}{|c|}{$\mathrm{DPBD}^{1}$} \\
\hline & 0.0 & 35.0 & 70.0 & 105.0 & 140.0 \\
\hline \multicolumn{6}{|c|}{ Neutral detergent fiber } \\
\hline 0 & $38.7 \mathrm{bC}$ & $75.6 \mathrm{aD}$ & $66.75 \mathrm{aD}$ & $65.2 \mathrm{aD}$ & $60.9 \mathrm{aD}$ \\
\hline 6 & $30.8 \mathrm{bC}$ & $75.8 \mathrm{aD}$ & $77.5 \mathrm{aD}$ & $59.7 \mathrm{aD}$ & $62.5 \mathrm{aD}$ \\
\hline 24 & $184.8 \mathrm{cB}$ & $186.2 \mathrm{cC}$ & $239.0 \mathrm{aC}$ & $215.7 \mathrm{bC}$ & $236.7 \mathrm{abC}$ \\
\hline 48 & $185.1 \mathrm{~dB}$ & $294.1 \mathrm{cB}$ & $324.1 \mathrm{bB}$ & $322.4 \mathrm{bB}$ & $353.0 \mathrm{aB}$ \\
\hline 96 & $533.7 \mathrm{aA}$ & $495.0 \mathrm{bA}$ & $504.0 \mathrm{bA}$ & $510.3 \mathrm{bA}$ & $497.3 \mathrm{bA}$ \\
\hline Equations* & $\mathrm{Y}=17.8+5.1 \mathrm{x}$ & $Y=68.7+4.5 x$ & $Y=82.0+4.6 x$ & $Y=67.6+4.8 x$ & $Y=78.2+4.7 x$ \\
\hline $\mathrm{R}^{2}$ & 0.94 & 0.99 & 0.97 & 0.98 & 0,94 \\
\hline \multicolumn{6}{|c|}{ Acid detergent fiber } \\
\hline 0 & $54.0 \mathrm{cD}$ & $67.4 \mathrm{bcD}$ & $69.6 \mathrm{bcD}$ & $118.7 \mathrm{aE}$ & $90.4 \mathrm{bD}$ \\
\hline 6 & $67.6 \mathrm{cD}$ & $77.0 \mathrm{bcD}$ & $89.0 \mathrm{bcD}$ & $170.2 \mathrm{aD}$ & $99.9 \mathrm{bD}$ \\
\hline 24 & $203.1 \mathrm{cC}$ & $228.9 \mathrm{cC}$ & $269.9 \mathrm{bC}$ & $273.3 b C$ & $312.8 \mathrm{aC}$ \\
\hline 48 & $315.6 \mathrm{cB}$ & $334.0 \mathrm{cB}$ & $366.9 \mathrm{bB}$ & $394.8 \mathrm{aB}$ & $404.7 \mathrm{aB}$ \\
\hline 96 & $501.4 \mathrm{cA}$ & $518.2 \mathrm{bA}$ & $529.6 \mathrm{bA}$ & $567.2 \mathrm{aA}$ & $542.6 \mathrm{abA}$ \\
\hline Equations* & $Y=63,2+4.7 x$ & $Y=78.5+4.8 x$ & $Y=63.2+4.4 x$ & $Y=144.8+4.6 x$ & $\mathrm{Y}=123.2+4.8 \mathrm{x}$ \\
\hline $\mathrm{R}^{2}$ & 0.98 & 0.98 & 0.98 & 0.98 & 0,91 \\
\hline \multicolumn{6}{|c|}{ Hemicellulose } \\
\hline 0 & $249.5 \mathrm{cE}$ & $324.0 \mathrm{bD}$ & $408.9 \mathrm{aC}$ & $416.4 \mathrm{aC}$ & $452 . .5 \mathrm{aD}$ \\
\hline 6 & $295.4 d D$ & $309.1 \mathrm{dD}$ & $375.1 \mathrm{cC}$ & $422.3 \mathrm{bC}$ & $505.8 \mathrm{aC}$ \\
\hline 24 & $336.7 \mathrm{cC}$ & $433.4 \mathrm{bC}$ & $610.0 \mathrm{aB}$ & $534.3 \mathrm{aB}$ & $590.0 \mathrm{aB}$ \\
\hline 48 & $467.2 \mathrm{cB}$ & $505.3 \mathrm{bcB}$ & $557.6 \mathrm{abB}$ & $578.1 \mathrm{aB}$ & 538.6abB \\
\hline 96 & $594.6 \mathrm{bA}$ & 651.1abA & $681.0 \mathrm{aA}$ & $691.4 \mathrm{aA}$ & $716.1 \mathrm{aA}$ \\
\hline Equations* & $Y=264.2+3.6 x$ & $Y=320.5+3.6 x$ & ns & $Y=428.2+2.9 x$ & $\mathrm{Y}=479.0+2,3 \mathrm{x}$ \\
\hline $\mathrm{R}^{2}$ & 0.98 & 0.97 & - & 0.95 & 0,91 \\
\hline
\end{tabular}

a, b Means followed by different letters in the row are different by $t$ test $(\mathrm{P}<0.05) .{ }^{\mathrm{A}, \mathrm{B}}$ Means followed by different letters in the column are different by $\mathrm{t}$ test $(\mathrm{P}<0.05)$. ${ }^{1} \mathrm{DPBP}$ - byproduct from dried pineapple. ${ }^{*}$ - significant at $1 \%$ probability level by $\mathrm{t}$ test. ns - not significant at $5 \%$ probability level by t test. $\mathrm{R}^{2}$ - coefficient of determination. Coefficient of experimental variation (CV) of Neutral detergent fiber $=8.77 \%$, Acid detergent fiber $=9.41 \%$ and of Hemicellulose $=2.86 \%$. 
Regarding the effect of addition of DPBP on the disappearance of NDF, it is likely that the better nutritive value, provided by the increased CP content, benefited the disappearance of the fibrous portion of these silages as compared with the exclusive elephant grass silages (Table 2). According to Krause et al. (2013), there is a cooperation between microorganisms in the rumen, for example, proteolytic and cellulolytic bacteria, and this synergism might have taken place in the silage with the highest DPBP content (140.0 $\mathrm{kg}^{-1}$ as fed). However, only after $24 \mathrm{~h}$ of incubation was it possible to observe an increase in the NDF disappearance of the silages, which may be attributed to the fiber quality. Rogério (2005) observed that the pineapple byproduct took a longer time to show differences in the degradation of NDF, as a function of the incubation times, and at $48 \mathrm{~h}$ and $96 \mathrm{~h}\left(357.5\right.$ and $\left.475.5 \mathrm{~g} \mathrm{~kg}^{-1}\right)$, the disappearance values were lower than those found for the elephant grass (466.0 and $616.3 \mathrm{~g} \mathrm{~kg}^{-1}$ ). Studying the addition of annatto byproduct in elephant grass silage, Rêgo et al. (2010) found that the disappearance of NDF at $96 \mathrm{~h}$ of incubation increased up to $16 \%$ of addition.

The ADF disappearance values followed the same trend as that obtained for NDF disappearance, i.e., only after $24 \mathrm{~h}$ of incubation was there an increase $(\mathrm{P}<0.05)$ in the disappearance of ADF (Table 4).

The ADF disappearance values followed the same trend observed for the disappearance of NDF, i.e., only after $24 \mathrm{~h}$ of incubation was there an increase in ADF disappearance. The increased disappearance of ADP observed with inclusion of DPBP must be related to the reduction of lignin contents with the addition of DPBP (Tables 1 and 2). The elevation in the proportion of this component in the fibrous fraction improves the resistance to hydrolysis by the rumen microorganisms, and the amount of this component in the matrix determines its protective ability against the cellulose degradation (VAN SOEST, 1994).
In the same way, Rogério (2005) observed an increase in ADF disappearance from pineapple byproduct only after $24 \mathrm{~h}$ of incubation. This disappearance ended at $96 \mathrm{~h}$, with 451.0 and 617.0 $\mathrm{g} \mathrm{kg}^{-1}$ for pineapple byproduct and elephant grass, respectively.

Both the incubation time and the levels of addition of DPBP to the ensilage of elephant grass influenced $(\mathrm{P}<0.05)$ the disappearance of hemicellulose (Table 4). At all incubation times, the silages containing $140.0 \mathrm{~g} \mathrm{~kg}^{-1} \mathrm{DPBP}$ as fed showed higher $(\mathrm{P}<0.05)$ hemicellulose disappearance values than those observed in the silage made with elephant grass only and containing $35.0 \mathrm{~g} \mathrm{~kg}^{-1} \mathrm{DPBP}$ as fed.

Despite the higher hemicellulose values of DPBP (366.2 $\left.\mathrm{g} \mathrm{kg}^{-1} \mathrm{DM}\right)$ in relation to the elephant grass (248.5 $\mathrm{g} \mathrm{kg}^{-1} \mathrm{DM}$ ), hemicellulose values decreased $(\mathrm{P}<0.05)$ with inclusion of DPBP (Table 2 ), which might have been a result of the use of this component by the lactic bacteria in the silo. It should be stressed that even with the decrease in hemicellulose concentration in the silages including DPBP, the residual hemicellulose of these silages seems to be more available or accessible to the rumen microorganisms than the hemicellulose from the exclusive elephant grass silage. This can be caused by the reduction in the concentration of lignin in the silages (Table 2), since lignin is more strongly bound to the hemicellulose (VAN SOEST, 1994). Thus, it appears that the increase in the level of addition of DPBP might have facilitated the greater availability of this nutrient to the rumen microbiota. Rogério (2005) observed equivalence in the hemicellulose disappearance values in the pineapple byproduct at the incubation times of 6 , 24, and $48 \mathrm{~h}$. However, in this period, the values were greater than those found for the elephant grass.

The increase observed in the ED of DM (Table 5) can be explained by the reduction of the cell wall components with the addition of DPBP (Tables 1 and 2). These results demonstrate that when compared 
with the quality of the elephant grass utilized in the silages, DPBP seems to improve the availability of nutrients for the rumen microbiota.

For the rumen degradation parameters of DM (Table 5), the increase in the levels of addition of DPBP led to an upward trend in the readily degradable fraction (a) and in the degradation rate of fraction b (c) or slowly degradable fraction. The fraction values ranged from 187.3 to $249.7 \mathrm{~g} \mathrm{~kg}^{-1}$ for the silages containing elephant grass exclusively and with addition of $105.0 \mathrm{~g} \mathrm{~kg}^{-1} \mathrm{DPBP}$ as fed, respectively. The degradation rates of fraction $b(c)$, however, varied from 15.7 to $26.2 \mathrm{~g} \mathrm{~kg}^{-1} \mathrm{~h}^{-1}$ for the silages of elephant grass only and containing 140.0 $\mathrm{g} \mathrm{kg}^{-1} \mathrm{DPBP}$ as fed, respectively.

Table 5. Parameters of degradability, effective degradability, and coefficient of determination $\left(\mathrm{R}^{2}\right)$ of the nutrients of silages for the passage rates of $0.02,0.05$ and $0.08 \mathrm{~h}^{-1}$.

\begin{tabular}{|c|c|c|c|c|c|c|c|}
\hline \multirow{3}{*}{$\mathrm{DPBD}^{1}$} & \multicolumn{3}{|c|}{ Parameters } & \multicolumn{3}{|c|}{ Effective degradability $^{2}$} & \multirow[b]{2}{*}{$\mathrm{R}^{2}$} \\
\hline & $\mathrm{a}$ & $\mathrm{b}$ & $\mathrm{c}$ & $0.02 \mathrm{~h}^{-1}$ & $0.05 \mathrm{~h}^{-1}$ & $0.08 \mathrm{~h}^{-1}$ & \\
\hline & \multicolumn{7}{|c|}{ Dry matter } \\
\hline 0.0 & 187.3 & 520.0 & 15.7 & 416.0 & 312.0 & 273.0 & 0.99 \\
\hline 35.0 & 200.3 & 495.6 & 16.5 & 424.0 & 323.0 & 285.0 & 0.99 \\
\hline 70.0 & 223.1 & 446.4 & 22.7 & 460.0 & 362.0 & 322.0 & 0.99 \\
\hline 105.0 & 249.7 & 497.7 & 16.1 & 472.0 & 371.0 & 333.0 & 0.99 \\
\hline \multirow[t]{2}{*}{140.0} & 236.6 & 441.4 & 26.2 & 487.0 & 388.0 & 345.0 & 0.99 \\
\hline & \multicolumn{7}{|c|}{ Crude protein } \\
\hline 0.0 & 178.9 & 640.0 & 14.2 & 445.0 & 320.0 & 275.0 & 0.97 \\
\hline 35.0 & 192.8 & 522.0 & 21.6 & 464.0 & 350.0 & 304.0 & 0.97 \\
\hline 70.0 & 218.8 & 642.4 & 15.1 & 495.0 & 368.0 & 321.0 & 0.97 \\
\hline 105.0 & 228.1 & 588.2 & 18.2 & 508.0 & 385.0 & 337.0 & 0.98 \\
\hline 140.0 & 233.0 & 628.0 & 18.0 & 530.0 & 399.0 & 348.0 & 0.98 \\
\hline
\end{tabular}

${ }^{1}$ DPBP - byproduct from dried pineapple; a - soluble fraction $\left(\mathrm{g} \mathrm{kg}^{-1}\right) ; \mathrm{b}$ - potentialy soluble fraction $\left(\mathrm{g} \mathrm{kg}^{-1}\right)$; $\mathrm{c}-\mathrm{degradation} \mathrm{rate}$ of $\mathrm{b}\left(\mathrm{g} \mathrm{kg}^{-1} \mathrm{~h}^{-1}\right){ }^{2} \mathrm{~g} \mathrm{~kg}^{-1}$ of nutrient.

Manoel et al. (2003) evaluated the degradability of DM from fruit pulp waste, and observed in pineapple byproduct $208.0 \mathrm{~g} \mathrm{~kg}^{-1} \mathrm{DM}$ for fraction $\mathrm{a}$, the degradation rate of $0.05 \mathrm{~h}^{-1}$, and effective degradability (ED) values of $492.0 \mathrm{~g} \mathrm{~kg}^{-1} \mathrm{DM}$ for the rate of $0.05 \mathrm{~h}^{-1}$. Casali et al. (2004), on the other hand, evaluated the degradability of elephant grass silages and found fraction a values of $147.3 \mathrm{~g} \mathrm{~kg}^{-1}$ $\mathrm{DM}$, and fraction c of $0.0274 \mathrm{~h}^{-1}$, and ED values of $323.7 \mathrm{~g} \mathrm{~kg}^{-1} \mathrm{DM}$ for the passage rate of $0.05 \mathrm{~h}^{-1}$, which are close values to those obtained in the exclusive elephant grass silages from the present study.
Working with silage of pineapple byproduct, Lallo et al. (2003) found mean values of 288.0 and $494.0 \mathrm{~g} \mathrm{~kg}^{-1} \mathrm{DM}$, respectively, for parameters a and $b$, and $0.042 \mathrm{~h}^{-1}$ for the degradation rate of $b$ (c) of DM. The ED was 623.0; 514.0 and $459.0 \mathrm{~g}$ $\mathrm{kg}^{-1} \mathrm{DM}$ for the passage rates of $0.02 ; 0.05$ and 0.08 $\mathrm{h}^{-1}$, respectively. Nevertheless, when these authors evaluated the replacement of corn silages $(0 ; 200.0$; 400.0 and $600.0 \mathrm{~g} \mathrm{~kg}^{-1}$ as fed) by the silages of pineapple industrial waste, they observed a decrease in fraction a and an increase in fraction b. Karkoodi et al. (2012), in turn, found low values for the apparent digestibility (562.2 $\left.\mathrm{g} \mathrm{kg}^{-1} \mathrm{DM}\right)$ and in situ 
degradability of DM, working with the evaluation of vegetable and fruit wastes for ruminants. The aforementioned authors concluded that these results might have been due to the high ash contents found in the byproducts.

Silages with inclusion of DPBP showed higher crude protein ED values in relation to the silage made of elephant grass exclusively, as a more likely result of the grater values of the soluble fraction (a) and the degradation rates of $b$ (c) (Table 5).

The variability in the values of $a, b$, and $c$ of $C P$ (Table 5) of the silages might be attributed to the characteristics of the ensiled material (chemical composition) and to the fermentation quality of the forage in the silo. Ferreira et al. (2009) evaluated the nutritional quality of DPBP and found no effects of its addition to elephant grass silage on the digestibility of CP (421.0 $\left.\mathrm{g} \mathrm{kg}^{-1} \mathrm{DM}\right)$. These authors reported that the low $\mathrm{CP}$ contents of the silages, coupled with the formation of protein complexes with the fibrous components (NDIN and ADIN), might have affected digestibility.

For the rumen degradation parameters of NDF, the soluble fraction (a) did not show large variations, ranging from $45.0 \mathrm{~g} \mathrm{~kg}^{-1}$ in the exclusive elephant grass silages and those with 105.0 and $140.0 \mathrm{~kg}^{-}$ ${ }^{1}$ DPBP as fed, to $54.2 \mathrm{~g} \mathrm{~kg}^{-1}$ in silages with $70.0 \mathrm{~g}$ $\mathrm{kg}^{-1} \mathrm{DPBP}$ as fed. The degradation rates of fraction $\mathrm{b}$ (c) varied from 10.6 to $15.3 \mathrm{~g} \mathrm{~kg}^{-1} \mathrm{~h}^{-1}$ for the silages composed of elephant grass only and those with $140.0 \mathrm{~g} \mathrm{~kg}^{-1}$ DPBP as fed, respectively (Table 6).

Table 6. Parameters of degradability, effective degradability, and coefficient of determination $\left(\mathrm{R}^{2}\right)$ of the nutrients of silages for the passage rates of $0.02,0.05$ and $0.08 \mathrm{~h}^{-1}$.

\begin{tabular}{cccccccc}
\hline & \multicolumn{7}{c}{ Parameters } \\
\hline \multirow{2}{*}{ DPBD $^{1}$} & $\mathrm{a}$ & $\mathrm{b}$ & $\mathrm{c}$ & $0.02 \mathrm{~h}^{-1}$ & $0.05 \mathrm{~h}^{-1}$ & $0.08 \mathrm{~h}^{-1}$ & $\mathrm{R}^{2}$ \\
\cline { 2 - 7 } & \multicolumn{7}{c}{ Effective degradability ${ }^{2}$} \\
\hline 0.0 & 45.0 & 615.0 & 10.6 & 258.0 & 153.0 & 117.0 & 0.89 \\
35.0 & 52.4 & 615.0 & 11.6 & 278.0 & 168.0 & 130.0 & 0.97 \\
70.0 & 54.2 & 615.0 & 13.1 & 298.0 & 182.0 & 141.0 & 0.98 \\
105.0 & 45.0 & 615.0 & 13.4 & 292.0 & 175.0 & 133.0 & 0.99 \\
140.0 & 45.0 & 588.9 & 15.3 & 300,0 & 183.0 & 140.0 & 0.97 \\
\hline \multicolumn{7}{c}{ Acid detergent fiber } \\
\hline 0.0 & 45.0 & 615.0 & 12.9 & 286.0 & 171.0 & 130.0 & 0.99 \\
35.0 & 51.1 & 615.0 & 13.8 & 302.0 & 184.0 & 141.0 & 0.98 \\
70.0 & 57.7 & 597.7 & 16.1 & 324.0 & 203.0 & 158.0 & 0.98 \\
105.0 & 119.3 & 615.0 & 12.9 & 360.0 & 245.0 & 204.0 & 0.99 \\
140.0 & 70.5 & 539.7 & 21.4 & 349.0 & 232.0 & 184.0 & 0.96 \\
\hline \multicolumn{7}{c}{ Hemicellulose } \\
\hline 0.0 & 290.0 & 395.0 & 12.1 & 439.0 & 367.0 & 342.0 & 0.97 \\
75.0 & 303.6 & 395.0 & 16.8 & 484.0 & 403.0 & 372.0 & 0.89 \\
70.0 & 383.2 & 296.4 & 31.0 & 563.0 & 497.0 & 466.0 & 0.61 \\
105.0 & 409.5 & 391.8 & 13.0 & 564.0 & 490.0 & 464.0 & 0.96 \\
140.0 & 450.0 & 395.0 & 10.1 & 583,0 & 517.0 & 494.0 & 0.60 \\
\hline
\end{tabular}

${ }^{1}$ DPBP - byproduct from dried pineapple; a - soluble fraction $\left(\mathrm{g} \mathrm{kg}^{-1}\right)$; b - potentialy soluble fraction $\left(\mathrm{g} \mathrm{kg}^{-1}\right)$; $\mathrm{c} \mathrm{-} \mathrm{degradation} \mathrm{rate}$ of $\mathrm{b}\left(\mathrm{g} \mathrm{kg}^{-1} \mathrm{~h}^{-1}\right){ }^{2} \mathrm{~g} \mathrm{~kg}^{-1}$ of nutrient. 
The silages with inclusion of DPBP had similar $(\mathrm{P}>0.05)$ values for the soluble fraction (a) of NDF, and displayed higher $(\mathrm{P}<0.05)$ values than the silage with elephant grass exclusively (Table 4). The values found in the silages with addition of DPBP (60.9 to $75.6 \mathrm{~g} \mathrm{~kg}^{-1}$ ) can be considered high, since the fibrous fraction is mostly insoluble. This fact can be explained by the greater passage of the material through the pores of the bags during washing.

The increase observed in the effective degradability of the silages as well as in the degradation rates of fraction $b$ (c) can be explained by the reduction of the components of the fibrous fraction (Tables 1 and 2). In this situation, the rate at which food leaves the rumen is an important factor in the regulation of the daily ingestion. The extent and rate of degradation of the plant tissue have a direct influence in the rate of passage through the digestive tract (VAN SOEST, 1994). However, Ferreira et al. (2009) did not observe an effect of addition of DPBP to the silage on the digestibility of NDF (552.0 $\left.\mathrm{g} \mathrm{kg}^{-1} \mathrm{DM}\right)$.

The ED values of ADF increased with addition of DPBP and varied from 130.0 to $360.0 \mathrm{~g} \mathrm{~kg}^{-1}$ for the passage rates of 0.08 to $0.02 \mathrm{~h}^{-1}$, respectively (Table 6). A lower ED of ADF in the pineapple byproduct as compared with the elephant grass was reported by Rogério (2005), who attributed this fact to the lower degradation rates (c) $\left(11.0 \mathrm{~g} \mathrm{~kg}^{-1} \mathrm{~h}^{-1}\right)$ and soluble fraction $\left(85.0 \mathrm{~g} \mathrm{~kg}^{-1}\right)$ of the pineapple byproduct in relation to elephant grass $\left(21.0 \mathrm{~g} \mathrm{~kg}^{-1}\right.$ $\mathrm{h}^{-1}$ and $\left.201.0 \mathrm{~g} \mathrm{~kg}^{-1} \mathrm{~h}^{-1}\right)$.

The soluble fraction (a) increased substantially, fostering the increase in ED of hemicellulose in the silages with inclusion of DPBP, which varied, respectively, from 342.0 to $583.0 \mathrm{~g} \mathrm{~kg}^{-1}$ for the passage rates of 0.08 to $0.02 \mathrm{~h}^{-1}$ (Table 6).

The soluble fraction increased substantially, fostering the increase in the ED of hemicellulose of the silages with addition of DPBP (Table 4), which corroborates Rogério (2005), who reported higher rates for the soluble fraction of the pineapple byproduct (243.4 $\mathrm{g} \mathrm{kg}^{-1}$ ) compared with elephant grass $\left(8.1 \mathrm{~g} \mathrm{~kg}^{-1}\right)$, and likewise for the ED of hemicellulose.

\section{Conclusions}

Dried pineapple byproduct is a potential alternative to be used as additive in the ensilage of elephant grass, as it provides an increase in the rumen degradability parameters at up to the inclusion level of $140 \mathrm{~g} \mathrm{~kg}^{-1}$ as fed.

\section{References}

ASSOCIATION OF OFFICIAL ANALYTICAL CHEMISTS - AOAC. Official methods of analysis. $15^{\text {th }}$ ed. Arlington: AOAC, 1990. $771 \mathrm{p}$.

CASALI, A. O.; REZENDE, A. V.; SIQUEIRA, G. R.; BARCELOS, A. F.; EVANGELISTA, A. R. LOPES, J. Degradabilidade ruminal in situ das silagens da mistura de capim-elefante com girassol. In: REUNIÃO ANUAL DA SOCIEDADE BRASILEIRA DE ZOOTECNIA, 41., 2004, Campo Grande. Anais... Campo Grande: SBZ, 2004. p. 1-5.

CORSI, M.; MARTHA JUNIOR, G. B.; NASCIMENTO JÚNIOR, D.; BALSALOBRE, M. A. Impact of grazing management on productivity of tropical grasslands. In: INTERNATIONAL GRASSLAND CONGRESS, BRAZIL, 19., 2001, São Pedro. Anais... São Pedro: SBZ, 2001. p. 801-806.

EVANGELISTA, A. R.; LIMA, J. D.; BERNARDES, T. F. Evaluation of some characteristics of star grass (Cynodon nlemfuensis Vanderyst) silage. Revista Brasileira de Zootecnia, Viçosa, MG, v. 29, n. 4, p. 941-946, 2000.

FERRARI JÚNIOR, E.; LAVEZZO, W. Qualidade da silagem de capim-elefante (Pennisetum purpureum Schum.) emurchecido ou acrescido de farelo de mandioca. Revista Brasileira de Zootecnia, Viçosa, MG, v. 30, n. 5, p. 1424-1431, 2001.

FERREIRA, A. C. H.; NEIVA, J. N. M.; RODRIGUEZ, N. M.; CAMPOS, W. E.; BORGES, I. Nutritional evaluation of pineapple industry byproduct as additive on elephant grass silage. Revista Brasileira de Zootecnia, Viçosa, MG, v. 38, n. 2, p. 223-229, 2009.

FERREIRA, A. C. H.; RODRIGUEZ, N. M.; NEIVA, J. N. M.; CAMPOS, W. E.; BORGES, I. Bromatologic and fermentative characteristics of silages of Napier grass mixed with increasing levels of pineapple industrial residues. Ceres, Viçosa, MG, v. 54, n. 312, p. 98-106, 2007. 
HABIB, G.; KHAN, N. A.; ALI, M.; BEZABIH, M. In situ ruminal crude protein degradability of byproducts from cereals, oilseeds and animal origin. Livestock Science, Oxford, v. 153, n. 1, p. 81-87, 2013.

HERRERA, M.; CHIN-JONES, R.; BOURRILLON, A. Características fermentativas y nutricionales del ensilaje del rastrojo de piña (Ananas escamosus). Agronomía Costarricense, San José, v. 33, n. 1, p. 1-15, 2009.

KARKOODI, K.; FAZAELI, H.; MIRGHAFFARI, S. S. Assessing the nutritive value of fruit and vegetable residues as ruminant feed. Turkish Journal of Veterinary and Animal Sciences, Ankara, v. 36, n. 3, p. 239-244, 2012.

KRAUSE, D. O.; NAGARAJA, T. G.; WRIGHT, A. D. G.; CALLAWAY, T. R. Board-invited review: rumen microbiology: leading the way in microbial ecology. Journal of Animal Science, Champaign, v. 91, n. 1, p. 331-341, 2013.

LALLO, F. H.; PRADO, I. N.; NASCIMENTO, W. G.; ZEOULA, L. M.; MOREIRA, F. B.; WADA, F. Y. Substitution levels of corn silage by pineapple byproducts on ruminal degradability in beef cattle. Revista Brasileira de Zootecnia, Viçosa, MG, v. 32, n. 3, p. 719-726, 2003.

LICITRA, G.; HERNANDEZ, T. M.; VAN SOEST, P. J. Standardization of procedures for nitrogen fractionation of ruminant feeds. Animal Feed Science and Technology, Oxford, v. 57, n. 4, p. 347- 358, 1996.

LLANO, D.; LÓPEZ, D.; MORA, F. Potencial del ensilaje de desechos de naranja (Citrus sinensis). Revista Ciencias Técnicas Agropecuarias, San José de las Lajas, v. 17, n. 1, p. 41-46, 2008.

MANOEL, A. O.; BANYS, V. L.; PEREIRA, R. C.; LOUSADA JÚNIOR, J. E.; CASTRO, A. L. A. Degradability of fruit pulp byproduct and extruded soybean. In: REUNIÃO ANUAL DA SOCIEDADE BRASILEIRA DE ZOOTECNIA, 40., 2003, Santa Maria. Anais... Santa Maria: SBZ, 2003. p. 1-4.

McDONALD, J. A revised model for the estimation of protein degradability in the rumen. The Journal of agricultural Science, Cambridge, v. 96, n. 1, p. 251-252, 1981.
ØRSKOV, E. R.; McDONALD, J. The estimation of protein degradability in the rumen from incubation measurements of feed in weighted according to rate of passage. The Journal of Agricultural Science, Cambridge, v. 92, n. 2, p. 499-503, 1979.

PEREIRA, E.; REGADAS FILHO, J. G. L.; FREITAS, E. R.; NEIVA, J. N. M.; CÂNDIDO, M. J. D. Energetic value from byproduct of the Brazil agroindustry. Archivos de Zootecnia, Cordoba, v. 58, n. 223, p. 455-458, 2009.

RÊGO, A. C.; CÂNDIDO, M. J. D.; PEREIRA, E. S.; FEITOSA, J. V.; RÊGO, M. M. T. Degradação de silagens de capim-elefante contendo subproduto do urucum. Revista Ciência Agronômica, Fortaleza, v. 41, n. 3, p. 482-489, 2010.

ROGÉRIO, M. C. P. Valor nutritivo de subprodutos de frutas para ovinos. 2005. Tese (Doutorado em Ciência Animal) - Universidade Federal de Minas Gerais, Belo Horizonte.

SAMPAIO, I. B. M. Contribuições estatísticas e de técnica experimental para ensaios de degradabilidade de forragens quando avaliada in situ. In: REUNIÃO ANUAL DA SOCIEDADE BRASILEIRA DE ZOOTECNIA, 31., 1994, Maringá. Anais...Maringá: SBZ, 1994. p. 81-82.

TOMICH, T. R.; SAMPAIO, I. B. M. A new strategy for the determination of forage degradability with an in situ technique through the use of one fistulated ruminant. The Journal of Agricultural Science, Cambridge, v. 142, n. 5, p. 589-593, 2004.

UPADHYAY, A.; LAMA, J. P.; TAWATA, S. Utilization of pineapple waste: a review. Journal of Food Science and Technology, Nepal, v. 6, p. 10-18, 2010.

VAN SOEST, P. J. Nutritional ecology of the ruminant. $2^{\text {th }}$ ed. Ithaca: Cornell University Press, 1994. 476 p.

VAN SOEST, P. J.; ROBERTSON, J. B.; LEWIS, B. A. Methods for dietary fiber, neutral detergent fiber, and nonstarch polysaccharides in relation to animal nutrition. Journal of Dairy Science, Madison, v. 74, n. 10, p. 35833597, 1991. 